\title{
Crude glycerol by transesterification process from used cooking oils: Characterization and potentialities on hydrogen bioproduction
}

\author{
Caroline Varella Rodrigues ${ }^{a, *}$, Kamili Oliveira Santana ${ }^{a}$, \\ Maurílio Gustavo Nespeca ${ }^{b, 1}$, José Eduardo de Oliveira ${ }^{b, 1}$, \\ Sandra Imaculada Maintinguer ${ }^{c, d}$
}

${ }^{a}$ Institute of Chemistry - IQ UNESP, Prof. Francisco Degni 55, Zip Code 14800-060, Araraquara, SP, Brazil

${ }^{\mathrm{b}}$ Center for Monitoring and Research of the Quality of Fuels, Biofuels, Crude Oil, and Derivatives, Institute of Chemistry - CEMPEQC, UNESP, Prof. Francisco Degni 55, Zip Code 14800-060, Araraquara, SP, Brazil

${ }^{c}$ Bioenergy Research Institute - IPBEN, UNESP, 13550-230, Rio Claro, SP, Brazil

d University Center of Araraquara, R. Voluntários da Pátria, 1309, Zip Code 14801-320, Araraquara, SP, Brazil

\section{A R T I C L E I N F O}

\section{Article history:}

Received 8 April 2016

Received in revised form

7 June 2016

Accepted 22 June 2016

Available online 14 July 2016

Keywords:

Anaerobic bacteria consortia

Crude glycerol

Hydrogen bioproduction

Used cooking oils

\begin{abstract}
A B S T R A C T
This study evaluated the potential bioconversion of crude glycerol from biodiesel production, applying used cooking oil for biohydrogen production by fermentative bacteria consortia. The pretreatment of crude glycerol was made by $\mathrm{pH}$ adjustment. Heat treatment of the inocula and initial pH 5.5 were applied to select hydrogen-producing bacteria and inactivate hydrogen-consumers microorganisms. The inocula tested were: (I) granular sludge from the thermophilic UASB reactor used on the treatment of vinasse and (II) granular sludge from the UASB reactor used on the treatment of sanitary sludge for the assays (1) and (2), respectively. The characterization of crude glycerol presented high levels of alkalinity, methanol and soap that may be inhibitory to biologic processes of $\mathrm{H}_{2}$ production. The assays were carried in anaerobic batch reactors in order to verify the efficiencies of crude glycerol to $\mathrm{H}_{2}$ generations by the microbial consortia (20\%) at $37^{\circ} \mathrm{C}$, initial pH 5.5, with $20.0 \mathrm{~g}$ COD L ${ }^{-1}$ glycerol. The cumulative production of hydrogen for the assays (1) and (2) were, respectively, $\left(\mathrm{mmol} \mathrm{H}_{2} \mathrm{~L}^{-1}\right.$ ) $28.49 \pm 1.55$ and $19.14 \pm 1.67$. The subsequent yields were obtained as follows: $2.2 \mathrm{moL} \mathrm{H}_{2} \mathrm{~mol}^{-1}$ glycerol and $1.1 \mathrm{moL} \mathrm{H}_{2} \mathrm{~mol}^{-1}$ glycerol, respectively. The used cooking oil was an efficient waste for bioconversion of crude glycerol to $\mathrm{H}_{2}$ production.

๑ 2016 Hydrogen Energy Publications LLC. Published by Elsevier Ltd. All rights reserved.
\end{abstract}

\section{Introduction}

Biodiesel is an alternative fuel and a renewable energy source, due to its availability of feedstock, for its requiring a very simple technology for its production and its role in greenhouse gases reduction [1,2]. The global biodiesel production has increased significantly with an average annual growth of $42 \%$ and is expected to reach 37 billion gallons by 2016 [3]. Conventionally, triglycerides are employed for biodiesel

\footnotetext{
* Corresponding author.

E-mail addresses: carolvr61@hotmail.com (C.V. Rodrigues), mainting2008@gmail.com (S.I. Maintinguer).

${ }^{1}$ Fax: +55 1633222308.
} 
production, such as virgin vegetable oils and animal fats, that are mixed with methanol and sodium hydroxide through catalyst processes [4]. The largest biodiesel marketing problem is the cost required for raw materials: about $70-95 \%$ of the total cost of production. The used cooking oil could be applied as a feedstock for biodiesel production with a reduction of costs of $60-70 \%$ [5], being two to three times cheaper than virgin vegetable oils [6]. The problems of the used cooking oil with your disposal via drainage or sanitary grounding, which may cause pollution of water and soil, they can be reduced using this waste as raw material for biodiesel production, that it can be an effective and economical approach to manage this energy source, providing a double benefit of fuel generation and environmental protection $[7,8]$.

Brazil is among the largest producers and consumers of biodiesel in the world, with a monthly production, in February 2016, of 271,388 $\mathrm{m}^{3}$ [9]. Since November 1st 2014, diesel marketed in Brazil contains $7 \%$ of biodiesel. This rule was established by the National Council of Energy Policy (CNPE) and increased from $5 \%$ to $7 \%$ the mandatory percentage of biodiesel mixture with diesel oil. The continuous increase in the percentage of biodiesel added to diesel has been demonstrating the success of the national program that tends to increase more and more the production of biodiesel.

A biodiesel production from a Brazilian pilot plant (University Center of Araraquara - Brazil) from used cooking oil by alkali-catalyzed transesterification processes has produced about $200 \mathrm{~L}$ of biodiesel through batch processes. The used cooking oils have been collected from houses, public schools and shops. The biodiesel produced supplies trucks that collect the used cooking oil, at a ratio of 50\% diesel and 50\% biodiesel, aiming at a cost reduction of 50\%. For an input of $80 \mathrm{~L}$ of used cooking oil (feedstock) in the process, $20 \mathrm{~L}$ correspond to methanol (short chain alcohol) and 30\% sodium hydroxide (catalyst) are pre-diluted in this alcohol, generating about $15 \mathrm{~L}$ of crude glycerol and $85 \mathrm{~L}$ of biodiesel.

Glycerol is the major byproduct of the biodiesel industry. In general, for every $100 \mathrm{~kg}$ of biodiesel that are produced, approximately $10 \mathrm{~kg}$ of crude glycerol (CG) are generated [10]. The glycerol is often called as crude glycerol due to its composition varies from one biodiesel plant to another in relation to feedstock oil composition and quality, the oil and methanol molar ratio, catalyst and the production process [11]. The impurities mainly present in this sample are soap, free fatty acids, methanol, unreacted triglycerides, diglycerides and monoglycerides [4]. The purification on CG was the most applied method before the boom of biodiesel production and utilized primarily in the cosmetic industry [11]. However, this purification is costly and hence its applications in food, pharmaceutical and personal care industries are not economically significant due to a decrease of the price of purified glycerol (1.54 US $\$ / \mathrm{Kg}$ before 2000 and $0.66 \mathrm{US} \$ / \mathrm{Kg}$ after 2007) $[4,11]$.

The increase in CG production and management of such a huge amount of waste will be a problem for biodiesel manufacturers [2]. According to Sarma et al. (2013) [2], the CG is an environmental hazard and its disposal in landfills must meet the universal treatment that further increase biodiesel waste disposal cost, thereby increasing the cost of biodiesel production [2]. So, using the CG as a substrate for bioconversion to value products, such as hydrogen generation through anaerobic digestion [2], the cost for biodiesel production could be cut down.

The impurities present in CG may lead to the inhibition of microorganism's development during the biological processes. The pretreatment of the CG by $\mathrm{pH}$ adjustment to acidic conditions may convert the soluble soaps to insoluble free fatty acid, so they can be separated, removed from crude glycerol and recycled. The fraction containing free fatty acids is collected on the surface of the glycerol phase and can be removed and recycled for one more esterification process $[4,12]$.

Dark Fermentation for the hydrogen production has advantages over photo-fermentation in terms of faster production, simple technique and no requirement of light energy [13]. The major advantage of dark fermentation consists of the wide range of organic substrates that fermenting bacteria can utilize for hydrogen production, such as wheat flour hydrolyzate and food waste hydrolyzate [14,15].

For biohydrogen production, a range of cheap and waste carbonaceous materials has been investigated as a substrate where good hydrogen yield has been achieved. In works involved pure glycerol as a feedstock for biohydrogen production, the high hydrogen yield has been reported. However, the cost to require pure glycerol is higher. So, the crude glycerol from biodiesel manufacturing process would be a preferred feedstock for hydrogen production. For large scale hydrogen production, CG seems to be the ideal substrate [4].

The amount of energy produced during the combustion of hydrogen per unit of weight is greater than the release for any other fuel, such as methane, gasoline, and others. Specifically, the amount of energy released during the hydrogen combustion reaction is about 2.5 times the power of combustion of a hydrocarbon. The main advantage of hydrogen as a fuel is the absence of $\mathrm{CO}_{2}$ emissions and other pollutants $[16,17]$.

Anaerobic processes of crude glycerol from biodiesel waste using either pure cell cultures (e.g. Clostridium butyricum, Escherichia coli) or mixed cultures (e.g. wheat soil, compost, and wastewater sludge) have been performed. Most of these studies were conducted in the anaerobic batch reactors, where the produced hydrogen is accumulated in the headspace of the bioreactors [2]. However, the majority of the researches are conducted with raw glycerol from virgin vegetable oils and animal fats [18]. In addition, the application of crude glycerol, from used cooking oils into biodiesel by transesterification processes, with fermentation by mixed cultures for $\mathrm{H}_{2}$ generation has never been employed.

In these sense, the main goal of this study consisted in the use of crude glycerol as a carbon source, from the transesterification process of used cooking oils, to obtain biodiesel, in anaerobic batch reactors in order to generate $\mathrm{H}_{2}$. The characterization of crude glycerol was performed and it was applied in assays of hydrogen bioproduction.

\section{Materials and methods}

\section{Crude glycerol (CG)}

CG was obtained from a Pilot Plant of Biodiesel Production from the Biotechnology Institute of Engineering Renewable Energy of 
UNIARA - University Center of Araraquara (Araraquara Brazil) through transesterification of used cooking oils.

\section{Characterization of CG}

\section{Glycerol}

The glycerol content of the CG sample was determined through spectrophotometric method. It is based on periodate oxidation of glycerol, leading to the formation of formaldehyde, followed by an optical density measurement at $410 \mathrm{~nm}$ [19].

\section{Soap}

The soap presented in CG was determined by titration and expressed as sodium oleate. A mixture of $60 \mathrm{~mL}$ of acetone and $0.15 \mathrm{~mL}$ of $0.5 \%(\mathrm{w} / \mathrm{v})$ bromophenol blue (in $95 \%$ ethanol) was prepared and neutralized with $0.01 \mathrm{M} \mathrm{NaOH}$. The solution was mixed with $10 \mathrm{~g}$ of CG sample and heated in a water bath $\left(70 \pm 1^{\circ} \mathrm{C}\right.$ ) for $1 \mathrm{~min}$. Later, the mixture was titrated using hydrochloric acid solution (0.1 M) [20].

$p H$

The determination of $\mathrm{pH}$ was made according to APHA (2005) [21].

Chemical oxygen demand (COD)

The COD was determined by APHA (2005) [21].

Moisture and volatile matter

The Moisture and Volatile Matter from the crude glycerol were determined by AOCS Ca 2c-25 [22].

\section{Ash}

The ash was analyzed by ABNT NBR 6294 [23].

\section{Water}

The water content was determined by volumetric Karl Fischer [24].

\section{Methanol}

The methanol concentrations were measured by gas chromatography, using a Shimadzu gas chromatography (GC model 2010), with Split/Splitless injector and a flame ionization detector (FID) of high frequency, a COMBI-PAL headspace auto-sampler system (AOC 5000), a programmable temperature vaporizing injector (PTV) and FID detector at the temperature of $300^{\circ} \mathrm{C}$. The oven temperature was programmed initially at $50{ }^{\circ} \mathrm{C}$ for $1 \mathrm{~min}$, followed by a heating ramp of $60{ }^{\circ} \mathrm{C} \mathrm{min}{ }^{-1}$ up to a final temperature of $250^{\circ} \mathrm{C}$, maintained for 2 min. The analytical column used was DB-1 MS $(20 \mathrm{~m} \times 0.10 \mathrm{~mm} \times 0.4 \mu \mathrm{m})$. As for the carrier gas used, it was hydrogen at a constant linear velocity of $63 \mathrm{cms}^{-1}$ (1 $\mathrm{mL} \mathrm{min}^{-1}$ ) and flow rate splitting (split) 1:100 [25].

Matter organic non glycerol (MONG)

MONG is based on the treatment of the crude glycerol in pH 2.0 for the separation of all matter organic non glycerol, in centrifuge at $9000 \mathrm{rpm}$ for $10 \mathrm{~min}$ [25].

\section{Appearance}

The appearance was determined through visual method [25].

\section{CG pretreatment}

The pretreatment was as it follows: the CG had the $\mathrm{pH}$ adjusted to around 3.0 with hydrochloric acid $(1 \mathrm{M})$ to convert the soluble soap into insoluble free fatty acids, which can be separated from the crude glycerol solution through centrifugation at $9000 \mathrm{rpm}$ for $7 \mathrm{~min}$, and the upper free fatty acid phase was removed from the crude glycerol phase through a separation funnel $[1,26]$.

\section{Obtained microbial consortia and growth conditions}

Hydrogen-producing bacteria were obtained from the inocula: (I) granular sludge of the thermophilic Upflow Anaerobic Sludge Blanket (UASB) reactor used in the treatment of vinasse (São Martinho, Pradópolis - Brazil) and (II) granular sludge from the UASB reactor used in the treatment of Municipal Sanitary sewage (São José do Rio Preto - Brazil).

The anaerobic batch reactors ( $100 \mathrm{~mL}$ - total volume) were prepared with PYG media modified $(50 \mathrm{~mL})$ composed of glycerin $\left(10.0 \mathrm{~g} \mathrm{~L}^{-1}\right)$, peptone $\left(5.0 \mathrm{~g} \mathrm{~L}^{-1}\right)$, yeast extract $\left(5.0 \mathrm{~g} \mathrm{~L}^{-1}\right)$ and meat extract $\left(5.0 \mathrm{~g} \mathrm{~L}^{-1}\right)$, at a $\mathrm{pH}$ of 7.0 , headspace filled with $\mathrm{N}_{2}$ (100\%). The reactors were sealed with aluminum crimp sealing containing rubber and sterilized $\left(120^{\circ} \mathrm{C}, 20 \mathrm{~min}\right)$. The cellular suspensions (20\% v/v) from inocula (I) and (II) were transferred separately to anaerobic batch reactors using a sterile syringe. The reactors were maintained at $37^{\circ} \mathrm{C}$ during 7 days without agitation.

After that, these samples of both inocula were submitted to heat treatment $\left(100{ }^{\circ} \mathrm{C}\right.$, for $\left.15 \mathrm{~min}\right)$ in order to inactivate the hydrogen consumers and harvest the spore-forming anaerobic bacteria, such as Clostridium sp. [27]. Serial dilutions on new sterile PYG media modified, pH 5.5 and headspace filled with $\mathrm{N}_{2}(100 \%)$ were performed and the cultures were used for the inoculation of the anaerobic batch reactors.

\section{Operation of the anaerobic batch reactors}

The anaerobic batch reactors were assembled in duplicate. The concentration of the carbon source in each reactor was of $20 \mathrm{~g} \mathrm{COD} \mathrm{L}^{-1}$ for all assays. In the assay (1) it was added as a carbon source, $50 \%$ of pretreated crude glycerol and $50 \%$ of glycerin, corresponding to $10 \mathrm{~g} \mathrm{COD} \mathrm{L}^{-1}$ of pretreated crude glycerol and $10 \mathrm{~g} \mathrm{COD} \mathrm{L}^{-1}$ of glycerin with the inoculum (I). Assay (2) was in the same condition, but with the inoculum (II). The inocula (1) and (2) were reactivated previously, separately, in a PYG medium, during $72 \mathrm{~h}$, in a PYG medium described early and kept at $37 \pm 1^{\circ} \mathrm{C}$, without agitation.

For each assay, $20 \%$ of the inocula (I) and (II) were reactivated and added separately to duplicates of anaerobic batch reactors $(1 \mathrm{~L})$ containing $650 \mathrm{~mL}$ of PYG media modified (5.0 $\mathrm{g} \mathrm{L}^{-1}$ of peptone, $5.0 \mathrm{~g} \mathrm{~L}^{-1}$ of yeast extract and $5.0 \mathrm{~g} \mathrm{~L}^{-1}$ of meat extract with different proportions of glycerin and pretreated crude glycerol, as described above), pH 5.5 and headspace filled with $350 \mathrm{~mL}$ of $\mathrm{N}_{2}(100 \%)$, kept at $37 \pm 1{ }^{\circ} \mathrm{C}$, without agitation. They were then capped with butyl rubber stoppers.

During the operation of anaerobic reactors, determinations of glycerol, $\mathrm{pH}$ and COD were made, according to what was previously described. 


\section{Microscopic analyses}

Morphological characteristics of the microorganisms were monitored through microscopy, using a Motic AE31 microscope. The images were captured using a Moticam 2000 camera and the MOTIC Images Plus 2.0 software with magnification at $1000 \mathrm{X}$ for both inocula.

\section{Chemical and chromatography analysis}

Hydrogen, methane and carbon dioxide determinations The biogas was determined through chromatographic analysis in a TOGA (Transformer Oil Gas Analyzer) system, coupled with a Trace GC Ultra-Thermo Gas Chromatograph, equipped with split/splitless injectors and two detectors: thermal conductivity detector (TCD) and FID with methanizer. The fraction containing hydrogen, nitrogen and methane was analyzed by a Rt-MSieve $5 \AA 30 \mathrm{~m} \times 0.53 \mathrm{~mm}$ i.d. column. Hydrogen and nitrogen were detected by TCD and methane was detected by FID, after going through the methanizer. The $\mathrm{CO}_{2}$ was eluted from the porous polymer Carboxen 1006 plot $30 \mathrm{~m} \times 0.53 \mathrm{~mm}$ i.d column and detected by the FID, after passing through the methanizer. Argon was used as a carrier gas (1.5 mL $\mathrm{min}^{-1}$ in splitless mode). The TCD detector and injector were adjusted to $150{ }^{\circ} \mathrm{C}$. The oven programing was at $50{ }^{\circ} \mathrm{C}(4.5 \mathrm{~min})$, under a heating rate $40^{\circ} \mathrm{C} \mathrm{min}-1$ to $180{ }^{\circ} \mathrm{C}$ (1.5 min), and then, under a cooling rate $50{ }^{\circ} \mathrm{C} \mathrm{min}-1$ to $50{ }^{\circ} \mathrm{C}$ (3.15 min). The production of $\mathrm{H}_{2}$ was calculated considering the atmospheric pressure, expressed as $\mathrm{mmol} \mathrm{H}_{2} \mathrm{~L}^{-1}$.

\section{Organic compounds in liquid medium}

The organic compounds concentrations were measured by gas chromatography (GC model 2010), configured for liquid and headspace sampling, a programmable temperature of PTV and FID detector at $250{ }^{\circ} \mathrm{C}$. The entire workstation was controlled by GC Solution version 2:32 program. The oven temperature was programmed initially at $45{ }^{\circ} \mathrm{C}$ for $1 \mathrm{~min}$, followed by a heating ramp of $50{ }^{\circ} \mathrm{C} \mathrm{min}^{-1}$ up to a final temperature of $250{ }^{\circ} \mathrm{C}$, maintained for $3 \mathrm{~min}$. The analytical column used was RTX-1 $(30 \mathrm{~m} \times 0.32 \mathrm{~mm} \times 3.0 \mu \mathrm{m})$. Helium was used as the carrier gas $51.6 \mathrm{cms}^{-1}\left(1 \mathrm{~mL} \mathrm{~min}^{-1}\right)$ [28].

\section{Volatile suspended solids (VSS)}

The VSS were determined according to APHA (2005), during the operation of anaerobic batch reactors [21].

\section{Cellular growth}

The cellular growth was monitored through optical density at $600 \mathrm{~nm}\left(\mathrm{OD}_{600}\right)$ [21]. The cellular mass was expressed in the form of volatile suspended solids (VSS $\mathrm{g} \mathrm{L}^{-1}$ ) and was calculated respectively by equation (1) for inoculum (I) and (2) for inoculum (II):

$$
\begin{aligned}
& \text { VSS }=0.0046 \times \mathrm{ABS}_{600}+0.0111, \mathrm{R}^{2}=0.9995 \\
& \mathrm{VSS}=0.0016 \times \mathrm{ABS}_{600}+0.0121, \mathrm{R}^{2}=0,9785
\end{aligned}
$$

\section{Analytical methods}

The experimental data obtained during the assays were adjusted to average values of duplicates in batch reactors using the software Statistic ${ }^{\circledR}$ (version 8.0). The maximum hydrogen production rate was obtained through sigmoidal nonlinear adjustment of the modified Gompertz equation [29] using equation (3).

$\mathrm{H}=\mathrm{P} \times \exp \left\{-\exp \left[\frac{\mathrm{Rm} \cdot \mathrm{e}}{\mathrm{P}}(\lambda-\mathrm{t})+1\right]\right\}$

Where $\mathrm{H}$ presents the cumulative hydrogen ( $\mathrm{mmol}$ ), $\mathrm{P}$ is the hydrogen production potential $\left(\mathrm{mmol} \mathrm{L}^{-1}\right), \mathrm{Rm}$ is the maximum rate of hydrogen production $\left(\mathrm{mmol} \mathrm{L}^{-1} \mathrm{~h}\right), \lambda$ is the lag phase time $(\mathrm{h})$, e is 2.718 and $\mathrm{t}$ is the incubation time $(\mathrm{h})$.

\section{Results and discussion}

\section{Crude glycerol (CG) characterization}

The main impurities in crude glycerol are soaps, methanol, methyl esters of fatty acids and glycerides. The concentrations of these components in CG depend on the oil feedstock and on the process used for biodiesel synthesis [30].

The high levels of alkalinity observed in crude glycerol could indicated that catalysts residues, such as $\mathrm{NaOH}$, coming from the transesterification process of used cooking oil, stayed in crude glycerol (Table 1). Mangayil et al. (2012) [31] had already worked with crude glycerol that contained high basicity ( $\mathrm{pH}$ 12.0) for the bioconversion of crude glycerol from biodiesel to $\mathrm{H}_{2}$, as observed in the present study. Hu et al. (2012) [32] studied the characterization of crude glycerol from waste vegetable oils from different biodiesel plants and they revealed a high basicity, with $\mathrm{pH}$ around 9.4, close to the results found in this study.

The ash content provides information about the catalyst used in the transesterification process, in which the most part migrates to the glycerin phase and calcined remain in the form of sodium or potassium salts. So, the value $3.04 \%$ of ash content (Table 1) on the present work confirms the presence of catalyst waste in crude glycerol, such as described on the literature. Hu et al. (2012) [32] obtained 2.7\% ash in the characterization of crude glycerol. Ayoub et al. (2012) [33] related on their paper that the commonly range of ash in crude glycerol could be around 1.5-2.5\%. Rossi et al. (2011) [34] used crude glycerol through biological processes and they observed $6.4 \%$ ash in order to generate hydrogen.

The COD obtained during the characterization of crude glycerol in this study (Table 1 ) showed a high value $(1961.33 \mathrm{~g}$ COD $\left.\mathrm{L}^{-1}\right)$, what indicates a residue involving a mixed raw material, such as impurities from used cooking oils with possible high organic load. Selembo et al. (2009) [35] studied the generation of $\mathrm{H}_{2}$ using mixed cultures of microorganisms with the addition of crude glycerol containing $1300 \mathrm{mg}$ COD $\mathrm{L}^{-1}$. This value of COD in the crude glycerol is probably due to the raw material used by the authors, that in this case, involved the transesterification process of virgin soybean oil 
Table 1 - Characterization of the crude glycerol used in the generation of $\mathbf{H}_{\mathbf{2}}$ biological assays.

\begin{tabular}{ccccccccc}
$\mathrm{pH}$ & $\begin{array}{c}\mathrm{COD} \\
\left(\mathrm{g} \mathrm{L}^{-1}\right)\end{array}$ & $\begin{array}{c}\text { Glycerol } \\
(\mathrm{m} / \mathrm{m}) \\
(\%)\end{array}$ & $\begin{array}{c}\text { Moisture and volatile } \\
\text { matter }(\%)\end{array}$ & Water $(\%)$ & Soap $(\mathrm{m} / \mathrm{m})(\%)$ & $\begin{array}{c}\text { Methanol } \\
(\mathrm{m} / \mathrm{m})(\%)\end{array}$ & $\begin{array}{c}\text { Ash } \\
(\mathrm{m} / \mathrm{m}) \\
(\%)\end{array}$ & $\begin{array}{c}\text { MONG } \\
(\mathrm{v} / \mathrm{v}) \\
(\%)\end{array}$ \\
\hline 10.00 & 1961.33 & 10.41 & 22.75 & 5.84 & 23.38 & 15.84 & 3.04 \\
\hline
\end{tabular}

in order to produce biodiesel with consequent generation of crude glycerol with a lower organic content than the one in the present study.

One of the most important parameters to establish the quality of glycerol from the biodiesel plants is their content on the total mass. The crude glycerol can contain any glycerol content, depending on the efficiency of the production process and quality of phase separation at the end of the transesterification reaction [30]. In the present study, $10.41 \%$ glycerol content were observed (Table 1) and these values were lower than the ones on the assays of Sarma et al. (2013) [36] with crude glycerol (23.63\% glycerol content) from biodiesel production process involving waste meat processing factories and fats from restaurants, for generating $\mathrm{H}_{2}$ with pure culture of Enterobacter aerogenes NRRL B 407. Valerio et al. (2015) [30] studied crude glycerol from farm biodiesel production and they observed a $15.4 \%$ glycerol content, higher values than the ones on the present study.

The water content observed was $5.84 \%$ (Table 1 ). The purification process of biodiesel can be made by washing with water or by dry wash. The dry wash was carried out in the pilot plant Ibiotec. This system consisted of two columns composed of mixed resins (cationic and anionic). The purification process was not held through washing with water, so the low content of water is justified and closer to the one related in literature. $\mathrm{Hu}$ et al. (2012) [32] determined the physical and chemical properties of different biodiesel derived from crude glycerol and they observed a $4.1 \%$ water content from waste vegetable oil. The typical composition of crude glycerol from biodiesel production in the study of Anger et al. (2011) [37] indicated a range of water content commonly found of $0-8 \%$, depending on the manufacturing process.

Methanol is considered one of the main impurities of the crude glycerol composition that is added to the transesterification process. Its presence is considered an inhibitory effect to microbial growth, and may as well interfere in the metabolic pathway to $\mathrm{H}_{2}$ generation. In this study, a content of $15.84 \%$ of methanol was observed. Higher values of methanol were found in the study of Ito et al. (2005) [38] with glycerol derived from biodiesel production. This value was of $25 \%$.

Moisture content and volatile materials found on crude glycerol were $22.75 \%$. As it had already been seen, it showed a water content of $5.84 \%$ and a methanol content of $15.84 \%$, the sum of the latter results is $21.68 \%$, approximate amount of what was found through the experimental methods, allowing us to infer that the crude glycerol had a composition essentially based on methanol and water.

An amount of $23.38 \%$ of soap was observed in the crude glycerol. The soap present in the crude glycerol is one of the largest impurities found and it is considered harmful to biomass and their metabolic activities, unfeasible [4]. Its formation is due to the raw material used, such as the used cooking oils, which may contain high concentrations of free fatty acids. These impurities, in the presence of base catalyst for the transesterification process, can generate saponified products in crude glycerol. In addition, the pretreatment process applied in this study had to be performed in order to reduce these interferences on $\mathrm{H}_{2}$ generation.

MONG is composed of coproducts from the transesterification process (mono-, di- and triglycerides) as well as free fatty acids. The low solubility of glycerol in long carbon chain esters (which are the main components of MONG) proves that there is a natural tendency for phase separation between the glycerol and MONG. However, at a high $\mathrm{pH}$, due to the excess of catalyst from the transesterification process, large amount of soaps is formed to make this natural separation of phase difficult. Therefore, during the determination of MONG, the $\mathrm{pH}$ of the crude glycerol was reduced to 2.0. Marques et al. (2009) [39] studied the generation of biohydrogen using crude glycerol containing $6.2 \%$ of MONG, a reduced value if compared to the ones in this study, which were $34.57 \%$.

During the "Determination of Appearance by Visual Method", there was no observation of precipitated material, consisting of just one liquid brown phase. The dark coloring is arisen from vegetable oil (used cooking oil) in association with MONG and other impurities that could be present in this residue.

The pretreatment applied to CG was efficient. The coloring after the acid treatment became clearer, showing that most of the MONG was eliminated and the COD of CG was reduced, with a value of $1071.79 \mathrm{~g} \mathrm{COD} \mathrm{L}^{-1}$. Chi et al. (2007) [1] applied a pretreatment in crude glycerol in order to convert soluble soaps into insoluble fatty acids that can be separated. This purified residue had become more suitable to be consumed by microorganisms with the objective of hydrogen generation, as in the present study.

According to Sarma et al. (2013) [2], the initial pH of CG is around 11-12, similar value found in the present study $(\mathrm{pH}$ 10.0), and after dilution with distilled water, total volume of the CG solution will be around $5 \mathrm{~L}$. So, at least $200 \mathrm{~mL}$ of $\mathrm{HCl}$ required for its $\mathrm{pH}$ adjustment the cost was approximately $\$ 2.38$, indicating an estimated to be spent in the pretreatment of the CG.

Ethier et al. (2011) [26] performed the pretreatment process of the CG, from a biodiesel plant that it was supplied with a mixture of $50 \%$ soybean oil and $50 \%$ chicken fat, by reducing the $\mathrm{pH}$ to 3 to eliminated soap. After this adjustment of CG, this sample was kept static for $30 \mathrm{~min}$ to allow free fatty acid and glycerol to separate into two phases. These impurities accounted for an inhibitory effect on cell growth, where this treated substrate was used to investigate the kinetics of growth and physiological parameters of microalgae Schizochytrium limacinum for the production of docosahexaenoic acid. 
In order to spend time for the natural separation of two phases formed after the acid pretreatment by kept the CG static, the centrifugation condition was used in the present study for accelerated this process. According to Chi et al. (2007) [1], the centrifugation condition at $5000 \mathrm{rpm}$ can separated this two phases.

\section{Operation of anaerobic batch reactors}

\section{Pretreatment of the inocula}

The microscopic analyses could directly be used for assessment of the microbial morphology. The heat treatment of the inocula and a pH 5.5 favored the maintenance of rods endospore-forming bacteria in the microbial consortia [Fig. 1 (a) and (b)]. Maintinguer et al. (2011) [40] observed rod and endospore-forming bacteria, using an inoculum from the slaughterhouse wastewater treatment UASB reactor, installed in Brazil. It was preheated at $90{ }^{\circ} \mathrm{C}$ for $15 \mathrm{~min}$, in order to inactivate the hydrogen consumers and harvest the sporeforming anaerobic bacteria, such as Clostridium sp. During the operation in anaerobic batch reactors, it was applied to hydrogen bioproduction ( $0.8 \mathrm{moL} \mathrm{H}_{2} \mathrm{~mol}^{-1}$ xylose).

The association of these two factors (heat treatment and initial pH 5.5) caused the inhibition of hydrogen-consuming microorganisms as methanogenic archaea, being that these microorganisms survive in $\mathrm{pH}$ varying from 6.3 to $7.8[27,41]$. The endospore-forming bacteria, such as Clostridium species, show a high $\mathrm{pH}$ tolerance. Facultative anaerobes such as Enterobacter and Klebsiella species have shown a very restricted optimal $\mathrm{pH}$ range between 5.0 and 6.0 for the production of hydrogen [34]. Maybe species of facultative and anaerobic bacteria were present during the assays of hydrogen bioproduction.

CG is mainly a carbonaceous material and, hence, the addition of a supplementary nutrient source could have improved its potential as a feedstock. In fact, an improvement in bioconversion efficiency has been observed through the addition of supplementary nutrient sources, such as peptone and yeast extracts $[2,42]$. Ito et al. (2005) [38] reported on their studies that the addition of both yeast extract and tryptone to the synthetic medium were effective in increasing the rates of $\mathrm{H}_{2}$ and ethanol production (initial $\mathrm{pH} 6.8,1.7 \mathrm{~g} \mathrm{~L}^{-1}$ of crude glycerol, $5 \mathrm{~g} \mathrm{~L}^{-1}$ of yeast extract and $5 \mathrm{~g} \mathrm{~L}^{-1}$ tryptone with a yield of $1.12 \mathrm{moL} \mathrm{H}_{2} \mathrm{~mol}^{-1}$ glycerol). Therefore, the use of a complex medium in the anaerobic batch reactors leads to a success in obtaining $\mathrm{H}_{2}$ in the presence of crude glycerol.

\section{Cell growth analysis}

The assays with anaerobic reactors (1 and 2), fed with CG, lead to different hydrogen generation. The initial concentrations of CG imposed were not inhibitory to the hydrogen-producing bacteria growth because there was an increase in the values of Volatile Suspended Solids (VSS) in all assays (1 and 2), which correspond basically to the microbial biomass present in the reactors. Cell growth was stabilized around $20 \mathrm{~h}$ of experiment for both inocula studied (Fig. 2). During this period it was seen exponential growth phase with subsequent nutrient consumption. A lag phase in the growth of biomass was not observed (Fig. 2). The maximum microbial growth was of $0.0161 \mathrm{~g} \mathrm{VSS} \mathrm{L}^{-1}$ for inoculum (I), and $0.0140 \mathrm{~g} \mathrm{VSS} \mathrm{L}^{-1}$ for inoculum (II), during $19.1 \mathrm{~h}$ and $19.9 \mathrm{~h}$ of operation, respectively.

\section{CG consumption in $\mathrm{H}_{2}$ generation assays}

The consumptions of CG were not complete during the two assays (Table 2). It was noted $26.9 \%$ and $31.7 \%$ of the glycerol consumptions of initial concentrations during $69.1 \mathrm{~h}$ and $68.7 \mathrm{~h}$ of operation to the assays (1) and (2) respectively. The presence of impurities from this residue probably caused

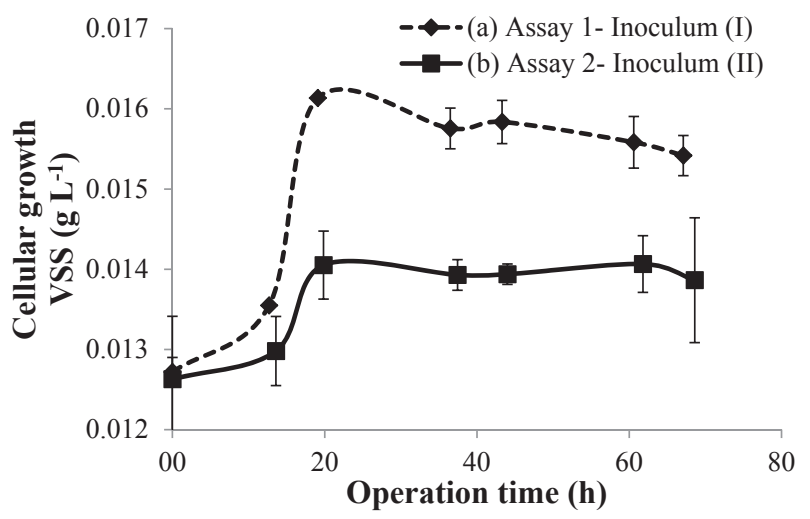

Fig. 2 - Temporal variation of bacterial growth on assays of $\mathrm{H}_{2}$ production: (a) Assay (1) - inoculum I, (b) Assay (2) inoculum II. (a)

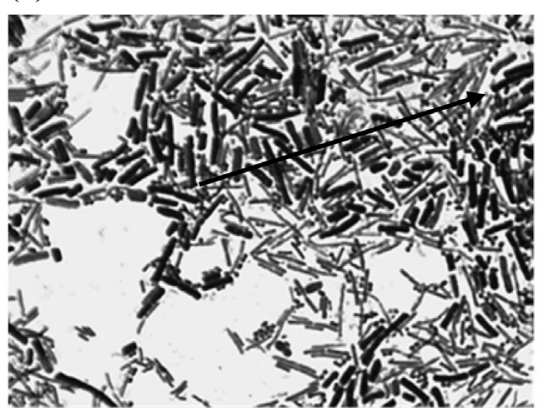

(b)

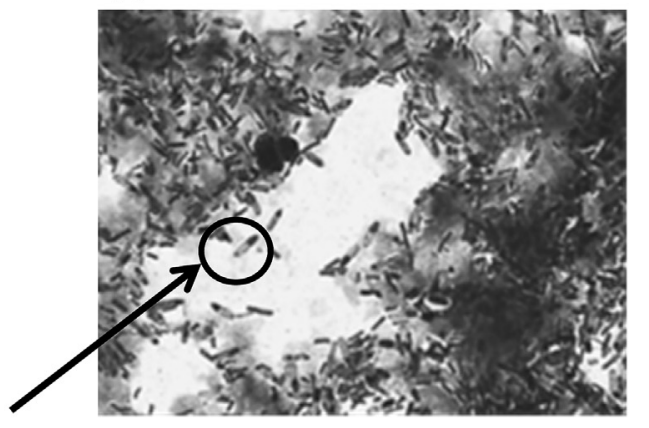

Fig. 1 - Microscopic analysis after cell purification: (a) inoculum (I) predominance of gram positive rods at magnifications of $1000 \mathrm{X}$; (b) inoculum (II) rods with endospores at magnifications of 1000X. 
some inhibition of the microbial growth, interfering with the metabolic pathways of both inocula (I and II) and low consumption of CG.

Ito et al. (2005) [38] observed total consumption of crude glycerol $\left(1.7 \mathrm{~g} \mathrm{~L}^{-1}\right)$, derived from biodiesel production plants, containing $25 \%$ of methanol, during $4 \mathrm{~h}$ of operation in anaerobic batch reactors, diluted in a complex medium ( $5 \mathrm{~g} \mathrm{~L}^{-1}$ yeast extract and $5 \mathrm{~g} \mathrm{~L}^{-1}$ tryptone) with a pure culture of E. aerogenes HU-101 at pH 6.8 and phosphate buffer. The total consumption of crude glycerol was expected because it was a pure culture and crude glycerol containing few impurities, once the crude glycerol was sterilized $\left(121^{\circ} \mathrm{C}, 18 \mathrm{~min}\right.$ ) before being inserted in the reactors. According to Sarma et al. (2012) [4], the simple fact of crude glycerol being sterilized helped eliminate a large quantity of methanol present, reducing greatly the inhibitory effect on microbial growth and promoting its high consumption.

Sarma et al. (2013) [36] operated anaerobic batch reactors filled with crude glycerol $\left(10 \mathrm{~g} \mathrm{~L}^{-1}\right)$ from transesterification processes of meat processing and restaurant residues with $0.37 \%$ soap content, pH 6.0, with E. aerogenes NRRL B 407 and a supplementary nutrient source for improved $\mathrm{H}_{2}$ production by CG bioconversion. The CG consumptions were from $60 \%$ to $95 \%$, high values if compared to those obtained in this study (Table 2). It is important to point out that the experiments involved pure cultures and sterile conditions that are inapplicable parameters for a large scale application. In addition, during the sterile conditions some impurities may be eliminated, mainly methanol, which is inhibitory for biological processes, as previously described.

\section{Chemical oxygen demand (COD)}

The COD values during the operation of the anaerobic batch reactors did not change significantly (Table 2). This fact can be explained by the glycerol metabolic pathway known for the fermentative $\mathrm{H}_{2}$-producing bacteria. During this metabolic pathway, some intermediates such as ethanol, butanol, acetate, butyrate are produced as metabolites of oxidative metabolism of glycerol [36]. This suggests that a

\begin{tabular}{|c|c|c|c|c|}
\hline Studied parameters & \multicolumn{2}{|c|}{ Assay (1) } & \multicolumn{2}{|c|}{ Assay (2) } \\
\hline $\operatorname{VSS}\left(\mathrm{g} \mathrm{L}^{-1}\right)$ & \multicolumn{2}{|c|}{0.0161} & \multicolumn{2}{|c|}{0.0140} \\
\hline Period (h) & \multicolumn{2}{|c|}{19.1} & \multicolumn{2}{|c|}{19.9} \\
\hline Glycerol consumption (\%) & \multicolumn{2}{|c|}{26.90} & \multicolumn{2}{|c|}{31.70} \\
\hline COD initial $\left(\mathrm{g} \mathrm{L}^{-1}\right)$ & \multicolumn{2}{|c|}{52.70} & \multicolumn{2}{|c|}{54.55} \\
\hline COD final $\left(\mathrm{g} \mathrm{L}^{-1}\right)$ & \multicolumn{2}{|c|}{49.52} & \multicolumn{2}{|c|}{54.15} \\
\hline pH (experiment end) & \multicolumn{2}{|c|}{5.68} & \multicolumn{2}{|c|}{5.70} \\
\hline Operation time (h) & \multicolumn{2}{|c|}{69.10} & \multicolumn{2}{|c|}{68.70} \\
\hline $\mathrm{P}\left(\mathrm{mmol} \mathrm{H} \mathrm{L}^{-1}\right)$ & \multicolumn{2}{|c|}{28.43} & \multicolumn{2}{|c|}{17.68} \\
\hline $\operatorname{Rm}\left(\mathrm{mmol} \mathrm{h}^{-1}\right)$ & \multicolumn{2}{|c|}{1.70} & \multicolumn{2}{|c|}{1.25} \\
\hline$\lambda(\mathrm{h})$ & \multicolumn{2}{|c|}{7.63} & \multicolumn{2}{|c|}{9.82} \\
\hline $\mathrm{R}^{2}$ & \multicolumn{2}{|c|}{1.00} & \multicolumn{2}{|c|}{0.99} \\
\hline max.conc. (mg L $\left.{ }^{-1}\right)$ & Initial & Final & Initial & Final \\
\hline Ethanol & 487.0 & 1845.0 & 183.0 & 903.0 \\
\hline Acetic acid & 507.0 & 583.0 & 272.0 & 807.0 \\
\hline Butyric acid & 143.0 & 305.0 & 59.0 & 705.0 \\
\hline $\begin{array}{l}\text { Hydrogen yield } \\
\text { (mol } \mathrm{H}_{2} \mathrm{~mol}^{-1} \text { glycerol) }\end{array}$ & \multicolumn{2}{|c|}{2.2} & \multicolumn{2}{|c|}{1.1} \\
\hline
\end{tabular}

transformation of the initial substrate into other volatile organic compounds happened, causing the maintenance of COD throughout the assays. Moreover, no methane generation was observed. This evidence confirmed the absence of $\mathrm{H}_{2}$-consuming microorganisms, such as archaea methanogenic, interfering directly in the maintenance of the COD in the liquid medium.

Kinetics of hydrogen production

The amounts of hydrogen production for the assays through the modified Gompertz equation fitted with correlation coefficients $R^{2}$ over 0.9 , which indicated the accuracy and precision of measurements [43], during the operation of the anaerobic reactors (Fig. 3).

Compounds of the organic liquid medium

High yields of $\mathrm{H}_{2}$ generation are obtained through the present study (Table 2). The main fermentative bacteria known to produce hydrogen include Enterobacter sp., Bacillus sp., Clostridium sp., Klebsiella sp. and Citrobacter sp. [18]. The glycerol metabolism and $\mathrm{H}_{2}$ production can be driven by two pathways: oxidative and reductive. During the oxidative metabolism of glycerol, pyruvate is formed as an intermediate and may be metabolized for different end products, such as ethanol, butanol, acetone, acetate, butyrate and lactate [4]. The generations of volatile organic compounds were monitored during the assays 1 and 2 (Fig. 4).

The methanol concentrations observed in the experiment (492.0 $\pm 0.0 \mathrm{mg} \mathrm{L}^{-1}$ for both assays) were not generated through biologic processes during the operation of the anaerobic batch reactors; it comes from the CG through a transesterification process of biodiesel. The main secondary metabolites produced in large quantity for both assays were ethanol (1845 $\mathrm{mg} \mathrm{L}^{-1}$ for assay 1 and $903 \mathrm{mg} \mathrm{L}^{-1}$ for assay 2), acetic acid (583 $\mathrm{mg} \mathrm{L}^{-1}$ for assay 1 and $807 \mathrm{mg} \mathrm{L}^{-1}$ for assay 2) and butyric acid (305 $\mathrm{mg} \mathrm{L}^{-1}$ for assay 1 and $705 \mathrm{mg} \mathrm{L}^{-1}$ for assay 2) (Table 2).

The $\mathrm{H}_{2}$ production is directly proportional to the generation of volatile organic compounds [44] in liquid medium. In most of the bioconversion of glycerol pathways, along with the different metabolites, $\mathrm{H}_{2}$ is also produced during oxidative

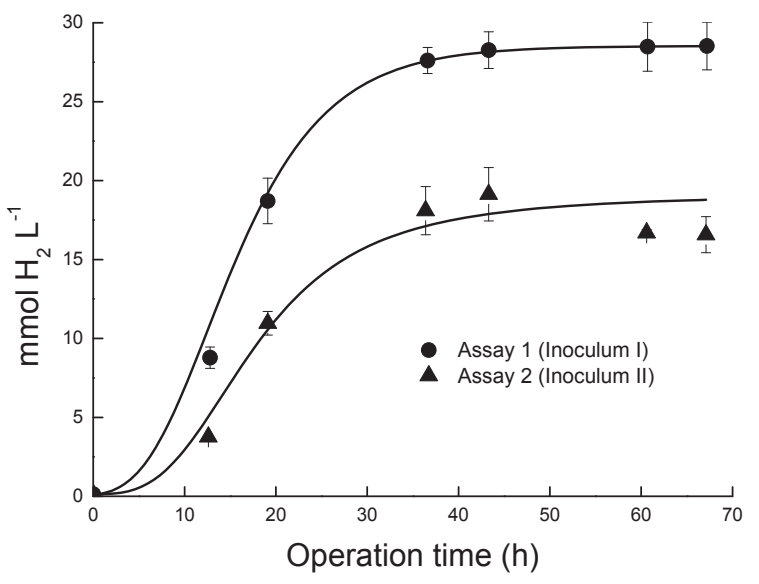

Fig. 3 - Generation of $\mathrm{H}_{2}$ using the modified Gompertz function in assays 1 and 2. 

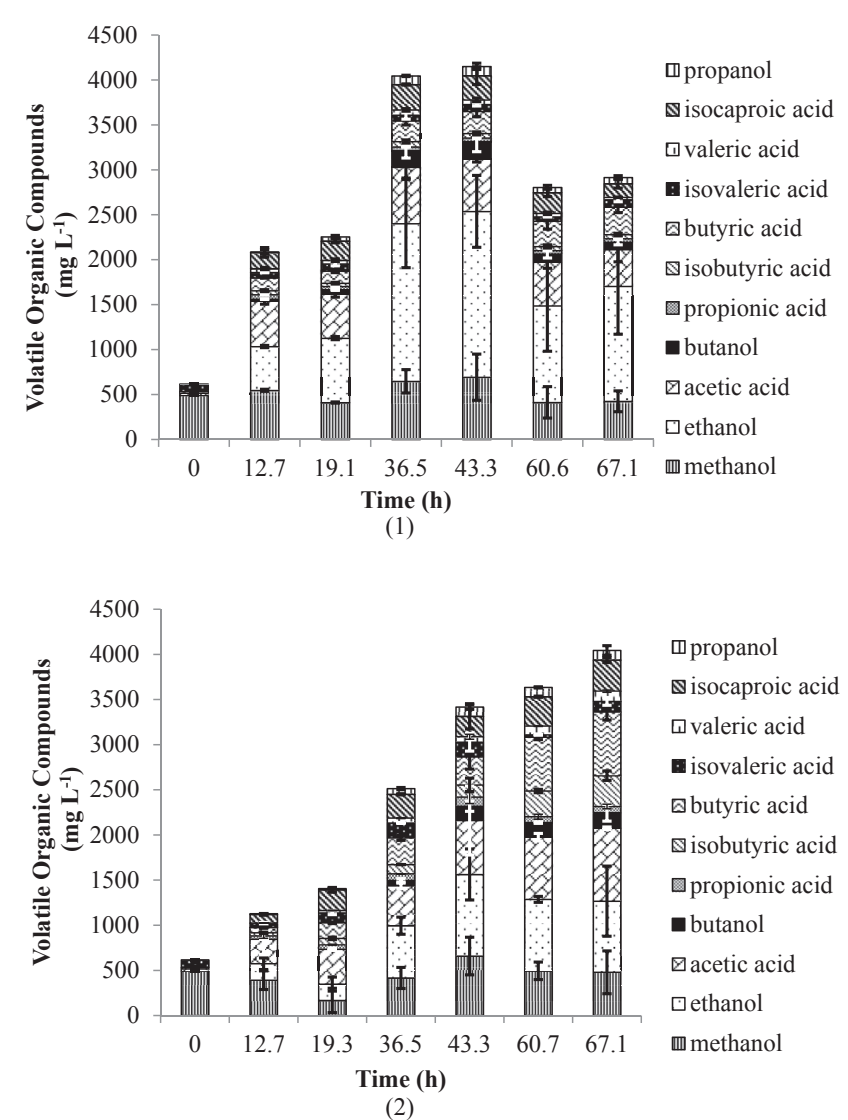

Fig. 4 - Proportion of the generated volatile organic compounds at each assays (1) and (2).

metabolism (Equations (4)-(7) below) [18]. It can be concluded that the generation of highly reduced final products is accompanied by high yields of $\mathrm{H}_{2}$ [4].

$$
\begin{aligned}
& \mathrm{C}_{3} \mathrm{H}_{8} \mathrm{O}_{3}+\mathrm{H}_{2} \mathrm{O} \rightarrow \mathrm{CH}_{3} \mathrm{COOH} \text { (acetic acid) }+\mathrm{CO}_{2}+3 \mathrm{H}_{2} \\
& 2 \mathrm{C}_{3} \mathrm{H}_{8} \mathrm{O}_{3} \rightarrow \mathrm{C}_{4} \mathrm{H}_{8} \mathrm{O}_{2} \text { (butyric acid) }+2 \mathrm{CO}_{2}+4 \mathrm{H}_{2} \\
& 2 \mathrm{C}_{3} \mathrm{H}_{8} \mathrm{O}_{3} \rightarrow \mathrm{C}_{4} \mathrm{H}_{10} \mathrm{O} \text { (butanol) }+2 \mathrm{CO}_{2}+\mathrm{H}_{2} \mathrm{O}+2 \mathrm{H}_{2} \\
& \mathrm{C}_{3} \mathrm{H}_{8} \mathrm{O}_{3} \rightarrow \mathrm{C}_{2} \mathrm{H}_{6} \mathrm{O} \text { (ethanol) }+\mathrm{CO}_{2}+\mathrm{H}_{2}
\end{aligned}
$$

It is observed that higher yields of $\mathrm{H}_{2}$ are possible when acetic acid is generated as an end product of the fermentation of glycerol, followed by butyric acid, butanol and ethanol [44].

The $\mathrm{H}_{2}$ productions were different in the conducted assays (Table 2). The anaerobic batch reactors were tested with two different inocula, previously described. An increase of acetic acid concentration is observed in the assay 2 (Table 2). According to the stoichiometry of glycerol fermentation involving the formation of acetic acid and butyric acid (equations (4) and (5), respectively), would be expected that the increase of these two acids in the assay 2 would led to increased production of $\mathrm{H}_{2}$. However, even for this assay, a lower generation of $\mathrm{H}_{2}$ was obtained [17.680 mmoL $\mathrm{H}_{2} \mathrm{~L}^{-1}$ (assay 2) and $28.434 \mathrm{mmoL} \mathrm{H}_{2} \mathrm{~L}^{-1}$ (assay 1)]. This can be explained by the fact that the $\mathrm{H}_{2}$ may have been used for more homoacetogens bacteria in order to form acetic acid. While the heat treatment in the inoculum was enough to prevent methanogenic archaea, it was not possible to prevent losses of $\mathrm{H}_{2}$, due to the presence of homoacetogens spore-forming bacteria [45] that can survive the extreme conditions of the pretreatment, such as Clostridium species, producing acetic acid from $\mathrm{H}_{2}$ and $\mathrm{CO}_{2}$ (Eq. (8)) [38].

$2 \mathrm{HCO}_{3}^{-}+4 \mathrm{H}_{2}+\mathrm{H}^{+} \rightarrow \mathrm{CH}_{3} \mathrm{COO}^{-}+\mathrm{H}_{2} \mathrm{O} \quad \Delta \mathrm{G}^{0}=-105 \mathrm{~kJ}$

Same way, yields from assay 1 were higher than the ones from assay 2 (Table 2). $\mathrm{H}_{2}$ production may also have been reduced due to the fact that the generation of ethanol from acetic acid and $\mathrm{H}_{2}$ was a thermodynamically favorable reaction (Eq. (9)) [46].

$$
\begin{aligned}
& \mathrm{CH}_{3} \mathrm{COOH}(\text { acetic acid })+2 \mathrm{H}_{2} \rightarrow \mathrm{C}_{2} \mathrm{H}_{6} \mathrm{O}(\text { ethanol })+\mathrm{H}_{2} \mathrm{O} \quad \Delta \mathrm{G}^{0} \\
& \quad=-49,51 \mathrm{~kJ}
\end{aligned}
$$

\section{Hydrogen generation yields}

Mangayil et al. (2015) [47] performed statistical studies to obtain better yields on the generation of $\mathrm{H}_{2}$ from the optimization of the culture medium with $1 \mathrm{~g} \mathrm{~L}^{-1}$ of crude glycerol (45\% glycerol and 30\% methanol, at $\mathrm{pH} 12,0$ ), through microbial consortium mainly composed of Clostridium species. The authors obtained yields of $1.41 \mathrm{moL} \mathrm{H}_{2} \mathrm{~mol}^{-1}$ glycerol. The yield of $\mathrm{H}_{2}$ generated on the study of these researchers was lower than that the one obtained in assay $1\left(2.2 \mathrm{moL} \mathrm{H}_{2} \mathrm{~mol}^{-1}\right.$ glycerol, Table 3). However, the crude glycerol obtained by the authors contained $45 \%$ glycerol content, higher than the one obtained on the present study (10.41\%). It can be concluded that even a crude glycerol containing lower glycerol amounts, high yields of generated hydrogen can be obtained. So, a CG from biodiesel process using used cooking oils has presented superior ability to generate hydrogen.

The study conducted by Varrone et al. (2012) [48] consisted of assays with mixed cultures and crude glycerol optimized nutritional conditions, $15 \mathrm{~g} \mathrm{~L}^{-1}$ (composition of 90\% glycerol, $7 \%$ salts, $2 \%$ ashes, $1 \%$ methanol and less than $0.4 \%$ moisture), derived from biodiesel production simultaneously for maximum production of hydrogen and ethanol, using statistical tools. The authors obtained, without the presence of trace elements, a $97.7 \%$ conversion of the CG with yields of $0.96 \mathrm{moL} \mathrm{H}_{2} \mathrm{~mol}^{-1}$ glycerol, generating as a major bioproduct $8 \mathrm{~g} \mathrm{~L}^{-1}$ of ethanol. On the present study, better results of hydrogen production were obtained without the addition of trace elements in the cultivation medium than on the study of Varrone et al. (2012) [48]. Even with a working up, CG starting concentration of $3.0 \mathrm{~g} \mathrm{~L}^{-1}$ with consumption of $56.2 \%$; values lower than those of these authors were obtained $\left(15 \mathrm{~g} \mathrm{~L}^{-1}\right.$ initial CG and consumption of $97.7 \%$ ). The yields achieved in the present study were higher than those showed by the author $\left(2.2 \mathrm{moL} \mathrm{H}_{2} \mathrm{~mol}^{-1}\right.$ glycerol from assay 1 and $1.1 \mathrm{moL}$ $\mathrm{H}_{2} \mathrm{~mol}^{-1}$ glycerol from assay 2, Table 2). It indicated the bioconversion ability of CG, from the transesterification process of used cooking oils, where initial concentrations of this substrate in this study were lower and, at the same time, it was able to generate high hydrogen yields.

Seifert et al. (2009) [49] worked with glycerol and anaerobic digested sludge, obtained from municipal wastes, in 


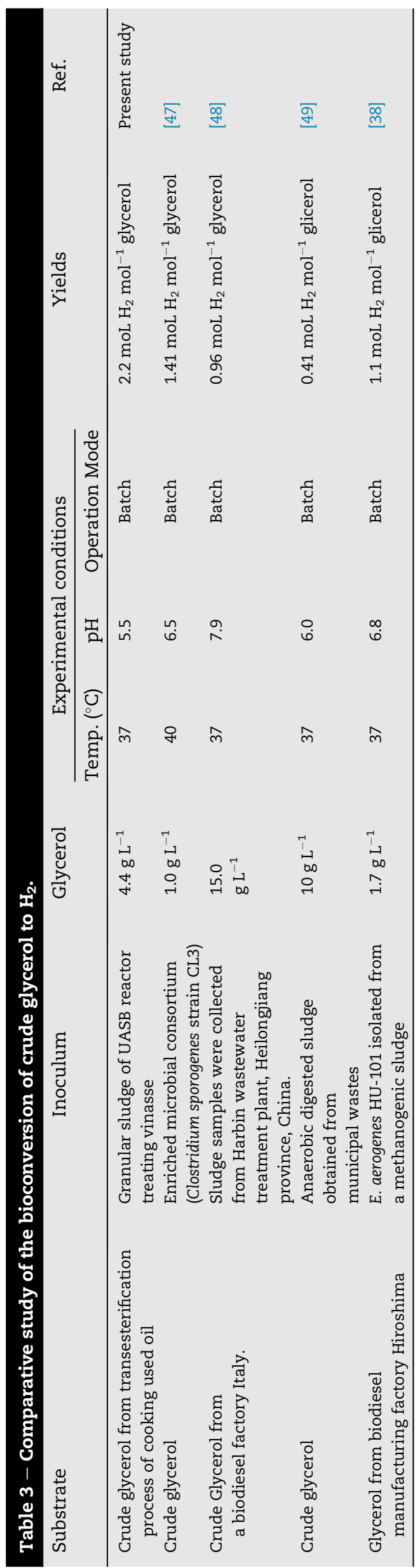

anaerobic batch reactor, for hydrogen production, with $10 \mathrm{~g} \mathrm{~L}^{-1}$ glycerol obtained as maximal substrate yield for hydrogen of $0.41 \mathrm{moL} \mathrm{H}_{2} \mathrm{~mol}^{-1}$ glycerol. It may lead to the conclusion that it is possible to produce hydrogen from CG in batch fermentation processes with activated municipal sludge as inoculum. The result showed by Seifert et al. is lower than the one shown by the present study $\left(2.2 \mathrm{moL} \mathrm{H}_{2} \mathrm{~mol}^{-1}\right.$ glycerol, Table 3), considering that the crude glycerol on the present study comes from a transesterification process using used cooking oils, had a lot of contaminants and that low concentrations of CG generated higher yields compared with Seifert et al. (2009), who used a greater concentration of glycerol, resulting in a lower yield. Both works used mixed cultures as inoculum.

Ito et al. (2005) [38] obtained a yield of $1.1 \mathrm{moL} \mathrm{H}_{2} \mathrm{~mol}^{-1}$ glycerol, in which the CG concentration was of $1.7 \mathrm{~g} \mathrm{~L}^{-1}$, working with a pure culture of $E$. aerogenes. Compared to the assay 1 (2.2 moL $\mathrm{H}_{2} \mathrm{~mol}^{-1}$ glycerol, Table 3 ) it was tested with a bacterial consortium and glycerol (41\% glycerol, $8 \%$ ash, 25\% methanol, $0.04 \%$ diacylglycerol and $0.01 \%$ monoacylglycerol) from transesterification of used cooking oils. Even this raw material carried impurities and contained low glycerol amount, compared to what was used on the experiments of Ito et al. (2005). The obtained yield proved that it is applicable to use this crude glycerol with mixed cultures to generate hydrogen.

According to the economic feasibility, Sarma et al. (2013) [2] studied the bioconversion of crude glycerol, from biodiesel manufacturing using vegetable oils, through two-stage fermentation, dark and photo-fermentation for bio-hydrogen production. According to them, $1 \mathrm{~kg}$ of hydrogen can replace 3.55 L of conventional diesel. For the bioconversion of $1 \mathrm{~kg}$ of CG for their studies, $45.6 \mathrm{~g}$ hydrogen and $4010.9 \mathrm{~L}$ biogas can be obtained. The energy content of the two fuels, hydrogen and biogas, biofuels produced from $1 \mathrm{Kg}$ of CG are capable of replacing 2.56 L of fossil diesel. Hence, 0.2 million metric tonne CG annually produced in North America can replace 512 million liters of fossil diesel worth 697.34 million dollar. Certain achievable alternative options for reduction of process cost could been applied, such as reduced the media constitutes, that represent about $82 \%$ of total process cost, increase initial CG concentration, use cheap nitrogen sources such as, slaughter house wastewater, brewery wastewater as well as active sludge from wastewater treatment plant as a supplementary nutrient for CG bioconversion process.

\section{Conclusions}

The impurities resulting from the used cooking oils and the transesterification process were identified and quantified in order to establish suitable pretreatments for the use in the assays of hydrogen generation. The pretreatment by $\mathrm{pH}$ adjustment applied in this study was efficient to obtain considerable amounts of $\mathrm{H}_{2}$ production, since most of the impurities that caused the inhibitory effect in the growth of the bacteria were removed.

During the assays, the methane generation was not observed in the two operational conditions. This corroborated the heat treatment efficiency and the $\mathrm{pH}$ control in order to inhibit the methanogenic archaea in both inocula. So, the 
bacterial consortia obtained from granular sludge of the inocula were capable to synthesize crude glycerol from used cooking oils with concomitant generation of $\mathrm{H}_{2}$.

The low $\mathrm{H}_{2}$ yields observed in the assay 2 associated with high acetic acid generations may be related to the presence of homoacetogens bacteria that consumed $\mathrm{H}_{2}$ to generate more acetic acid. The high ethanol generations from the conducted assays could prove that the $\mathrm{H}_{2}$ may have been required by the acetic acid to form ethanol molecules in a thermodynamically favorable reaction.

Hydrogen bioproduction from crude glycerol of biodiesel production processes through used cooking oils and granular sludges of biologic treatment from tropical climate are sustainable environmental applications of these wastes. Thus, this study showed that it is possible to obtain a sustainable biodiesel production, considering that the crude glycerol, coproduct generated, can be extensively used for bioconversion of hydrogen with efficiency.

\section{Acknowledgments}

The authors gratefully acknowledge the financial support from Fundação de Amparo a Pesquisa do Estado de São Paulo (FAPESP - Proc 2012/01318-1), Conselho Nacional de Pesquisa e Desenvolvimento (CNPq) - Proc CNPq 457144/2014-9, CAPES for the scholarship and CEMPEQC for support the chromatography analyses.

\section{R E F E R E N C E S}

[1] Chi Z, Pyle D, Wen Z, Frear C, Chen S. A laboratory study of producing docosahexaenoic acid from biodiesel-waste glycerol by microalgal fermentation. Process Biochem 2007;42(11):1537-45.

[2] Sarma SJ, Brar SK, Le Bihan Y, Buelna G. Bio-hydrogen production by biodiesel-derived crude glycerol bioconversion: a techno-economic evaluation. Bioprocess Biosyst Eng 2013;36(1):1-10.

[3] Lee CS, Aroua MK, Daud WMAW, Cognet P, Pérès-Lucchese Y, Fabre P-L, et al. A review: conversion of bioglycerol into 1,3propanediol via biological and chemical method. Renew Sustain Energy Ver 2015;42:963-72.

[4] Sarma SJ, Brar SK, Sydney EB, Bihan YL, Buelna G, Soccol CR. Microbial hydrogen production by bioconversion of crude glycerol: a review. Int J Hydrogen Energy 2012;37(8):6473-90.

[5] Gupta AR, Yadav SV, Rathod VK. Enhancement in biodiesel production using waste cooking oil and calcium diglyceroxide as a heterogeneous catalyst in presence of ultrasound. Fuel 2015;158:800-6.

[6] Kiakalaieh AT, Amin NAS, Mazaheri H. A review on novel processes of biodiesel production from waste cooking oil. Appl Energy 2013;104:683-710.

[7] Yaakob Z, Mohammad M, Alherbawi M, Alam Z, Sopian K. Overview of the production of biodiesel from Waste cooking oil. Renew Sustain Energy Rev 2013;18:184-93.

[8] Diya'uddeen BH, Aziz ARA, Daud WMAW, Chakrabarti MH Performance evaluation of biodiesel from used domestic waste oils: a review. Process Saf Environ Prot 2012;90(3):164-79.
[9] ANP. Agência Nacional do Petróleo, Gás Natural e Biocombustíveis, Boletim mensal do biodiesel, março. Rio de Janeiro: ANP; 2016. http://www.anp.gov.br [accessed 22.03.16].

[10] Rivero M, Solera R, Perez M. Anaerobic mesophilic codigestion of sewage sludge with glycerol: enhanced biohydrogen production. Int J Hydrogen Energy 2014;39(6):2481-8.

[11] Zhang X, Yan S, Tyagi RD, Surampalli RY, Valéro JR. Energy balance of biofuel production from biological conversion of crude glycerol. J Environ Manag 2016;170:169-76.

[12] Santori G, Nicola GD, Moglie M, Polonara F. A review analyzing the industrial biodiesel production practice starting from vegetable oil refining. Appl Energy 2012;92:109-32.

[13] Pachapur VL, Sarma SJ, Brar SK, Bihan YL, Buelna G, Soccol CR. Evidence of metabolic shift on hydrogen, ethanol and 1,3-propanediol production from crude glycerol by nitrogen sparging under micro-aerobic conditions using coculture of Enterobacter aerogenes and Clostridium butyricum. Int J Hydrogen Energy 2015;40(28):8669-76.

[14] Han W, Wang XN, Ye L, Huang JG, Tang JH, Li YF, et al. Fermentative hydrogen production using wheat flour hydrolysate by mixed culture. Int J Hydrogen Energy 2015;40(13):4474-80.

[15] Han W, Liu DN, Shi YW, Tang JH, Li YF, Ren NQ. Biohydrogen production from food waste hydrolysate using continuous mixed immobilized sludge reactor. Bioresour Technol 2015;180:54-8.

[16] Marbán G, Valdés-Sólis T. Towards hydrogen economy? Int J Hydrogen Energy 2005;32(12):1625-37.

[17] Santos FM, Santos FA. Combustível "hidrogénio". Millenium. 2005. p. 252-70.

[18] Maintinguer SI, Hatanaka RR, De Oliveira JE. Glycerol as a raw material for hydrogen production. In: Biernat Krzysztof, editor. Biofuels - status and perspective; 2015. http:// dx.doi.org/10.5772/60013. ISBN: 978-953-51-2177-0, InTech, http://www.intechopen.com/books/biofuels-status-andperspective/glycerol-as-a-raw-material-for-hydrogenproduction [accessed 31.10.15].

[19] Bondioli P, Bella DL. An alternative spectrophotometric method for the determination of free glycerol biodiesel. Eur J Lipid Sci Technol 2005;107(3):153-7.

[20] CODEX, http://www.oiv.int/oiv/files/CODEX_2012_EN.pdf [accessed 22.03.16].

[21] APHA AWWA WEF. Standard methods for the examination of water and wastewater: American Public Health Association. 21th ed. American Water Works Association, Water Environment Federation; 2005 [Centennial Edition].

[22] AOCS. Moisture and volatile matter, air oven method. AOCS official method Ca 2c-25 (97). Champaign, IL: AOCS Press; 1998.

[23] ASSOCIAÇÃO BRASILEIRA DE NORMAS TÉCNICAS. NBR 6294: óleos lubrificantes e aditivos: determinação de cinza sulfatada. 2008. p. 8. Rio de Janeiro.

[24] ASTM D4017. Standard test method for water in paints and paint materials by the Karl fischer titration method. 2002.

[25] Sequinel R. Caracterização físico-química da glicerina proveniente de usinas de bio- diesel e determinação de metanol residual por CG com amostragem por Headspace estático. PhD Thesis. UNESP - Instituto de Química de Araraquara; 2013.

[26] Ethier S, Woisard K, Vaughan D, Wen Z. Continuous culture of the microalgae Schizochytrium limacinum on biodieselderived crude glycerol for producing docosahexaenoic acid. Bioresour Technol 2011;102(1):88-93.

[27] Maintinguer SI, Fernandes BS, Duarte ICS, Saavedra NK, Adorno MAT. Varesche. Fermentative hydrogen production 
by microbial consortium. Int J Hydrogen Energy 2008;33(16):4309-17.

[28] Adorno MAT, Hirasawa JS, Varesche MBA. Development and validation of two methods to quantify volatile acids (C2-C6) by GC/FID: headspace (Automatic and Manual) and Liquid-Liquid Extraction (LLE). Am J Anal Chem 2014;5:406-14.

[29] Lay J-J, Li Y-Y, Noike T. Developments of bacterial population and methanogenic activity in a laboratory-scale landfill bioreactor. Water Res 1998;32(12):3673-9.

[30] Valerio O, Horvath T, Pond C, Misra M, Mohanty A. Improved utilization of crude glycerol from biodiesel industries: synthesis and characterization of sustainable biobased polyesters. Ind Crops Prod 2015;78:141-7.

[31] Mangayil R, Karp M, Santala V. Bioconversion of crude glycerol from biodiesel production to hydrogen. Int J Hydrogen Energy 2012;37(17):12198-204.

[32] Hu S, Luo X, Wan C, Li Y. Characterization of crude glycerol from biodiesel plants. J Agric Food Chem 2012;60(23):5915-21.

[33] Ayoub M, Abdullah AZ. Critical review on the current scenario and significance of crude glycerol resulting from biodiesel industry towards more sustainable renewable energy industry. Renew Sustain Energy 2012;16(5):2671-86.

[34] Rossi DM, Da Costa JB, De Souza EA, Peralba MCR, Samios D, Ayub MAZ. Comparison of different pretreatment methods for hydrogen production using environmental microbial consortia on residual glycerol from biodiesel. Int J Hydrogen Energy 2011;36(8):4814-9.

[35] Selembo PA, Perez JM, Lloyd WA, Logan BE. Enhanced hydrogen and 1,3-propanediol production from glycerol by fermentation using mixed cultures. Biotechnol Bioeng 2009;104(6):1098-106.

[36] Sarma SJ, Brar SK, Bihan YL, Buelna G, Soccol CR, Naceur M, et al. Evaluation of different supplementary nutrients for enhanced biohydrogen production by Enterobacter aerogenes NRRL B 407 using waste derived crude glycerol. Int J Hydrogen Energy 2013;38(5):2191-8.

[37] Anger S, Trimis D, Stelzner B, Makhynya Y, Peil S. Development of a porous burner unit for glycerine utilization from biodiesel production by supercritical water reforming. Int J Hydrogen Energy 2011;36(13):7877-83.

[38] Ito T, Nakashimada Y, Senba K, Matsui T, Nishio N. Hydrogen and ethanol production from glycerol-containing wastes discharged after biodiesel manufacturing process. J Biosci Bioeng 2005;100:260-5.

[39] Marques PASS, Bartolomeu ML, Thomas MM, Neves LM. Biohydrogen production from glycerol by a strain of Enterobacter aerogenes. Hypothesis VIII. In: Proceeding of Hypothesis VIII; 2009 April 1e3; Lisbon, Portugal; 2009.

[40] Maintinguer SI, Fernandes BS, Duarte ICS, Saavedra NK, Adorno MAT, Varesche MBA. Fermentative hydrogen production with xylose by Clostridium and Klebsiella species in anaerobic batch reactors. Int J Hydrogen Energy 2011;36(21):13508-17.

[41] Li C, Fang HHP. Fermentative hydrogen production from wastewater and solid wastes by mixed cultures. Crit Rev Environ Sci Technol 2007;37(1):1-39.

[42] Ueno Y, Haruta S, Ishii M, Igarashi Y. Microbial community in anaerobic hydrogen-producing microflora enriched from sludge compost. Appl Microbiol Biotechnol 2001;57(4):555-62.

[43] Sivagurunathan P, Kumar G, Park J-H, Park H-D, Yoon J-J, Kim S-H. Feasibility of enriched mixed cultures obtained by repeated batch transfer in continuous hydrogen fermentation. Int J Hydrogen Energy 2016;41(7):4393-403.

[44] Maintinguer SI, Sakamoto IK, Adorno MAT, Varesche MBA. Bacterial diversity from environmental sample applied to bio-hydrogen production. Int J Hydrogen Energy 2015;40:3180-90.

[45] Lazaro CZ, Perna V, Etchebehere C, Varesche MBA. Sugarcane vinasse as substrate for fermentative hydrogen production: the effects of temperature and substrate concentration. Int J Hydrogen Energy 2014;39:6407-18.

[46] Oh S-E, Ginkel SV, Logan BE. The relative effectiveness of pH control and heat treatment for enhancing biohydrogen gas production. Environ Sci Technol 2003;37(22):5186-90.

[47] Mangayil R, Aho T, Karp M, Santala V. Improved bioconversion of crude glycerol to hydrogen by statistical optimization of media components. Renew Energy 2015;75:583-9.

[48] Varrone C, Giussani B, Izzo G, Massini G, Marone A, Signorini A, et al. Statistical optimization of biohydrogen and ethanol production from crude glycerol by microbial mixed culture. Int J Hydrogen Energy 2012;37(21):16479-88.

[49] Seifert K, Waligorska M, Wojtowski M, Laniecki M. Hydrogen generation from glycerol in batch fermentation process. Int $J$ Hydrogen Energy 2009;34(9):3671-8. 